\title{
Reduction of Calcium Currents by Lambert-Eaton Syndrome Sera: Motoneurons Are Preferentially Affected, and L-Type Currents Are Spared
}

\author{
Kelly D. García and Kurt G. Beam \\ Department of Anatomy and Neurobiology, Colorado State University, Fort Collins, Colorado 80523
}

Previous work has demonstrated that Lambert-Eaton syndrome (LES) antibodies reduce calcium currents in nonneuronal cells and sensory neurons and reduce the amplitude of extracellularly recorded currents at mouse motor nerve terminals. We compared effects of LES sera on whole-cell currents of cultured nerve and muscle. LES sera more strongly reduced calcium currents in motoneurons than in sensory neurons. Motoneuronal potassium currents were unaffected. The sera minimally affected calcium currents in skeletal and cardiac muscle. In motoneurons, both low voltage-activated (LVA) and high voltage-activated (HVA) components of calcium current were decreased, demonstrating that the sera targeted more than one calcium channel type. The HVA current remaining in LES-treated motoneurons was little affected by micromolar $\omega$-conotoxin MVIIC but was reduced $>70 \%$ by micromolar nimodipine. This pharmacological profile contrasts with untreated cells and suggests that LES sera primarily spare L-type currents in motoneurons.

Key words: calcium channels; calcium currents; motoneurons; Lambert-Eaton myasthenic syndrome; neuromuscular transmission; transmitter release
Lambert-Eaton myasthenic syndrome (LES) is an autoimmune disorder characterized by decreased neurotransmitter release at the neuromuscular junction (Elmqvist and Lambert, 1968; Lambert and Elmqvist, 1971). Ultrastructural analysis has revealed that motoneurons from LES patients have fewer active zones, which are less well organized, and contain fewer active zone particles (Fukunaga et al., 1982). Because active zones are the sites of neurotransmitter release and the active zone particles are thought to include the calcium channels necessary for neurotransmitter release (Couteaux and Pecot-Dechavassine, 1970; Heuser et al., 1979), it is widely accepted that LES antibodies target presynaptic calcium channels (Fukunaga et al., 1982). To test this hypothesis, the effects of LES antibodies on radiocalcium fluxes or calcium currents have been examined in a number of systems. The antibodies reduce calcium influx in small-cell lung carcinoma (Roberts et al., 1985), rat anterior pituitary (Login et al., 1987), adrenal chromaffin (Kim and Neher, 1988; Viglione et al., 1992), neuroblastoma (Peers et al., 1990; Grassi et al., 1994), rat thyroid cell line (Kim et al., 1993) and dorsal root ganglion (DRG) cells (García et al., 1996). Recently, it has been shown that LES antibodies decrease mixed sodium and calcium currents at the nerve terminals of mice (Smith et al., 1995). Mice are an appropriate model, because the disease can be transferred passively to them (Fukunaga et al., 1983; Kim, 1986). However, the effects of LES antibodies on isolated calcium currents in motoneurons have not been examined. Here, we describe such experiments on murine motoneurons, which is particularly important because asso-

\footnotetext{
Received April 17, 1996; accepted May 21, 1996.

This work was supported by National Institutes of Health Grant NS26416 to K.G.B. We thank Dr. Donald Sanders for the serum samples and Robin Morris for help with the tissue culture. This work is from a thesis submitted to the Academic Faculty of Colorado State University in partial fulfillment of the requirements for the degree of Ph.D. to K.D.G.

Correspondence should be addressed to Dr. Beam at the above address. Copyright (C) 1996 Society for Neuroscience $0270-6474 / 96 / 164903-11 \$ 05.00 / 0$
}

ciated proteins, rather than the calcium channels per se, might be the critical antigenic target (Leveque et al., 1992).

Neurons contain a variety of calcium channel types that can be divided into low voltage-activated (LVA) or T-type channels and high voltage-activated (HVA) channels (Nowycky et al., 1985). HVA channels can be subdivided on the basis of molecular, biophysical, and pharmacological properties and include L, N, P, O, Q, and R channels (Nowycky et al., 1985; Fox et al., 1987; Mintz et al., 1992; Regan et al., 1992; Olivera et al., 1994; Randall and Tsien, 1995). Previous experiments have not examined thoroughly the types of calcium channels affected or spared by LES antibodies. Furthermore, the calcium channel makeup of motoneurons is likely to be different from other cell types examined previously. It is especially important to characterize the types of calcium channels affected by LES antibodies in motoneurons, because the specific channel type or types critical for neurotransmitter release seem to vary between synapses (Hirning et al., 1988; Stanley and Goping, 1991; Turner et al., 1993; Wheeler et al., 1994) and the type or types that govern transmitter release at the mammalian neuromuscular junction remain unclear. Based on pharmacological criteria, N, P, and Q channels all have been suggested to be important. A critical role for P-type channels was argued on the basis of the blocking of neuromuscular transmission in mice by a polyamine fraction of funnel-web spider venom (Uchitel et al., 1992). However, divergent results have been reported for the effects of a peptide, $\omega$-AgaIVa, which now is used widely as the spider venom component specific for P-channels at nanomolar concentrations (Mintz et al., 1992). Thus, Hong and Chang (1995) reported that murine neuromuscular transmission was blocked by $10 \mathrm{~nm} \omega$-AgaIVa but was almost unaffected by 300 $\mu \mathrm{M}$ of the cone shell venom $\omega$-CTx MVIIC. By contrast, Bowersox et al. (1995) found that a complete block required a much higher concentration $(\sim 300 \mathrm{nM})$ of synthetic $\omega$-AgaIVa (SNX-290) and a much lower concentration $(1 \mu \mathrm{M})$ of synthetic $\omega$-CTx MVIIC (SNX-230). Thus, these studies make it uncertain whether P or Q 
channels are involved, because near-micromolar concentrations of $\omega$-AgaIVa and $\omega$-CTx MVIIC block both P and Q channels. Adding further to the controversy, early work demonstrated that the N-channel toxin, $\omega$-CgTx GVIA, did not affect murine neuromuscular transmission (Yoshikami et al., 1989), whereas a more recent report showed significant reduction of nerve-evoked muscle contractions in rats by 3 nM of the toxin (Rossoni et al., 1994).

We report here that LES sera from four patients significantly reduce calcium currents in murine motoneurons. Comparatively, these sera cause a lesser decrease in calcium currents in DRG neurons (previously reported by García et al., 1996) and have little effect on muscle. Within motoneurons, voltage-gated potassium channels are not affected, both LVA and HVA calcium currents are decreased, and the HVA calcium current remaining in LES serum-treated motoneurons is mostly L-type.

\section{MATERIALS AND METHODS}

Motoneuron cultures. The procedures used for the preparation of motoneuron cultures were similar to those reported previously (Mynlieff and Beam, 1992a,b). So that they could be identified, neonatal murine motoneurons were labeled retrogradely with a suspension of $2.5 \mathrm{mg} / \mathrm{ml}$ 1,1'-dioctadecyl-3,3,3'3'-tetramethylindocarbocyanine perchlorate (diI; Molecular Probes, Eugene, OR), 20\% ethanol, and 80\% rodent Ringer with $0.1 \%$ bovine serum albumin. Each mouse pup was anesthetized with Metofane, and the diI suspension was injected into all four limbs. After being returned to its mother for several hours $(9-11)$ to allow the dye to label motoneuronal cell bodies, the pup was anesthetized and decapitated, and the spinal cord was removed in oxygenated rodent Ringer (in $\mathrm{mM}$ ): $146 \mathrm{NaCl}, 5 \mathrm{KCl}, 2 \mathrm{CaCl}_{2}, 1 \mathrm{MgCl}_{2}, 10 \mathrm{HEPES}$, and 11 glucose, $\mathrm{pH}$ 7.4. Care was used to dissect away the meninges and any attached DRGs to ensure that the culture was not contaminated with labeled sensory cells. The spinal cord was cut into small pieces $\left(<1 \mathrm{~mm}^{3}\right)$ and placed in $0.5 \mathrm{ml}$ of a $0.1 \%$ Type XI trypsin and $0.01 \%$ DNase I (both from Sigma, St. Louis, MO) solution in PIPES-buffered saline (in mM): $120 \mathrm{NaCl}, 5$ $\mathrm{KCl}, 1 \mathrm{CaCl}_{2}, 1 \mathrm{MgCl}_{2}, 25$ glucose, and 20 piperazine- $N$, $N^{\prime}$-bis(2ethanesulfonic acid), $\mathrm{pH}$ 7.0. After $15-20 \mathrm{~min}$ of incubation at $35^{\circ} \mathrm{C}$, the tissue was rinsed with neural basal medium containing B27 supplement (Life Technologies, Grand Island, NY), $100 \mu \mathrm{g} / \mathrm{ml}$ streptomycin, and 60 $\mu \mathrm{g} / \mathrm{ml}$ penicillin and triturated with a fire-polished pipette. The cells were plated on $35 \mathrm{~mm}$ dishes that had been coated overnight by exposure to poly-L-lysine (4-15 kDa; $1 \mathrm{mg} / \mathrm{ml}$ in $0.15 \mathrm{M}$ boric acid, $\mathrm{pH}$ 8.4). Serum from either normal humans or one of the LES patients was dialyzed (exclusion of $\geq 100 \mathrm{kDa}$ ) for $24 \mathrm{hr}$ against culture medium at a sample/ dialysate ratio of $\sim 1: 100$ with one dialysate change at $\sim 8 \mathrm{hr}$ (García et al., 1996). Dialyzed serum was added to the culture medium at $\sim 1: 20$ dilution at the time of cell plating. Cells were recorded from after being maintained overnight in a humidified atmosphere of $95 \%$ air $/ 5 \% \mathrm{CO}_{2}$ at $37^{\circ} \mathrm{C}$.

Ionic currents. The whole-cell patch-clamp configuration (Hamill et al., $1981)$ was used to record ionic currents at room temperature $\left(20^{\circ} \mathrm{C}\right)$ with a Dagan 3900 patch-clamp amplifier (Dagan Corporation, Minneapolis, MN) equipped with a 3911 whole-cell expander. The patch electrodes (3-4 M $\Omega$ ) were made from soda lime glass and coated with wax to reduce capacitance. Linear components of leak and capacitive currents were removed from test currents by digital subtraction of scaled control currents elicited by $20 \mathrm{mV}$ hyperpolarizations from the holding potential $(-80 \mathrm{mV})$. Currents were filtered electronically at $1 \mathrm{kHz}(8$ pole Bessel filter) before sampling by the computer. To normalize for differences in total membrane area, current densities were calculated by dividing total current by the linear capacitance of the cell. Data are expressed as mean \pm SEM. Least-squares fits were computed with NFIT software (Island Software, Galveston, TX).

To measure calcium currents, recording electrodes contained (in $\mathrm{mM}$ ): 140 Cs-aspartate, $5 \mathrm{MgCl}_{2}, 10 \mathrm{Cs}_{2}$ EGTA, and 10 HEPES, $\mathrm{pH} 7.4$; the extracellular recording medium contained $10 \mathrm{CaCl}_{2}, 145$ tetraethylammonium-chloride (TEA-Cl), tetrodotoxin (TTX; 0.003 for muscle cells, 0.0005 for motoneurons), and 10 HEPES, pH 7.4. To measure potassium currents, recording electrodes contained (in $\mathrm{mM}$ ): $140 \mathrm{KCl}, 5$ $\mathrm{MgCl}_{2}, 10 \mathrm{~K}_{2}$ EGTA, and 10 HEPES, $\mathrm{pH} 7.4$; the external solution contained $146 \mathrm{NaCl}, 5 \mathrm{KCl}, 2 \mathrm{CaCl}_{2}, 1 \mathrm{MgCl}_{2}, 0.001 \mathrm{TTX}$, and 10 HEPES, pH 7.4.

Nimodipine was made up as a $10 \mathrm{~mm}$ stock solution in ethanol. Stock solutions of $0.5 \mathrm{~mm} \omega$-CTx MVIIC were prepared by dissolving the peptide in distilled water with $1 \mathrm{mg} / \mathrm{ml}$ bovine serum albumin and stored in aliquots at $-20^{\circ} \mathrm{C}$. Stock solutions were diluted to final concentrations on the day of use in the external solution used for measuring calcium currents. For population studies, cultures were placed in the solutions containing either $\omega$-CTx MVIIC or nimodipine $1.5 \mathrm{hr}$ before recording. In perfusion experiments, small wells were created that isolated cells in each culture dish. After the currents from a cell under control conditions were recorded, the well was perfused with drug solution $(>6 \times$ volume exchange).

\section{RESULTS}

Serum was obtained from four patients (Patients I, II, III, and IV) diagnosed as having LES. Patient IV was diagnosed also as having myasthenia gravis by virtue of having antibodies characteristic of both conditions (Leys et al., 1989). Spinal cords containing motoneurons labeled by intramuscular injection (Honig and Hume, 1986) of diI were dissociated and incubated overnight with serum from either normal individuals or from one of the four patients. Serum was added to the culture medium at a 1:20 dilution, which results in an immunoglobulin concentration approximately equivalent to that circulating in adult human blood (Isselbacher et al., 1980). Although the majority of recordings $(>80 \%)$ was from diI-labeled cells, some data were from cells identified as motoneurons on the basis of size and morphology (Smith et al., 1986; Milligan et al., 1994; Mynlieff and Beam, 1994).

\section{Calcium currents obtained from control serum- and LES serum-treated motoneurons}

Calcium currents were elicited with $300 \mathrm{msec}$ depolarizing pulses from a holding potential of $-80 \mathrm{mV}$ to test potentials from -50 to $+50 \mathrm{mV}$ at $10 \mathrm{mV}$ intervals. Figure 1 compares currents from a motoneuron treated with control serum (left) and a motoneuron treated with LES serum (right). In both the control and LEStreated cells, the calcium currents displayed LVA and HVA components. However, at all test potentials the calcium currents in the LES-treated motoneuron were much smaller than those in the control motoneuron. Moreover, the sustained HVA component $(+10 \mathrm{mV})$ represented a larger fraction of the total current in LES-treated cells than in control cells (sustained equaled 55\% of total current in control as compared with 66, 74, 65, and $72 \%$ in Patients I-IV, respectively). Additionally, the HVA component of current from cells treated with LES serum seemed to have a slower time course of activation, although the small size of the currents made a detailed quantitative analysis difficult.

Calcium currents were recorded from five groups of motoneurons to quantify the effects of LES serum: a control group that was treated with control serum and four test groups, each of which was treated with serum from one of the four LES patients (Fig. 2). The amplitude of current was divided by cell capacitance and expressed as current density $(\mathrm{pA} / \mathrm{pF})$ to normalize for variability in cell size. Current densities recorded from individual cells were averaged for each of the five groups. Currents from the control cells displayed LVA and HVA components similar to those described previously in neonatal murine motoneurons (Mynlieff and Beam, 1992a). In particular, the amplitude of the maximal HVA current $(\sim 5 \mathrm{pA} / \mathrm{pF})$ was almost identical to that found by Mynlieff and Beam. Average current densities were smaller at all test potentials in the LES serum-treated cells, with the largest reductions for Patients II and IV. At both -20 and $+20 \mathrm{mV}$ (approximate potentials eliciting peak LVA and HVA currents, respectively), the reduction of current amplitude was statistically significant $(p<0.05)$ for all four patients. 


\section{Control}

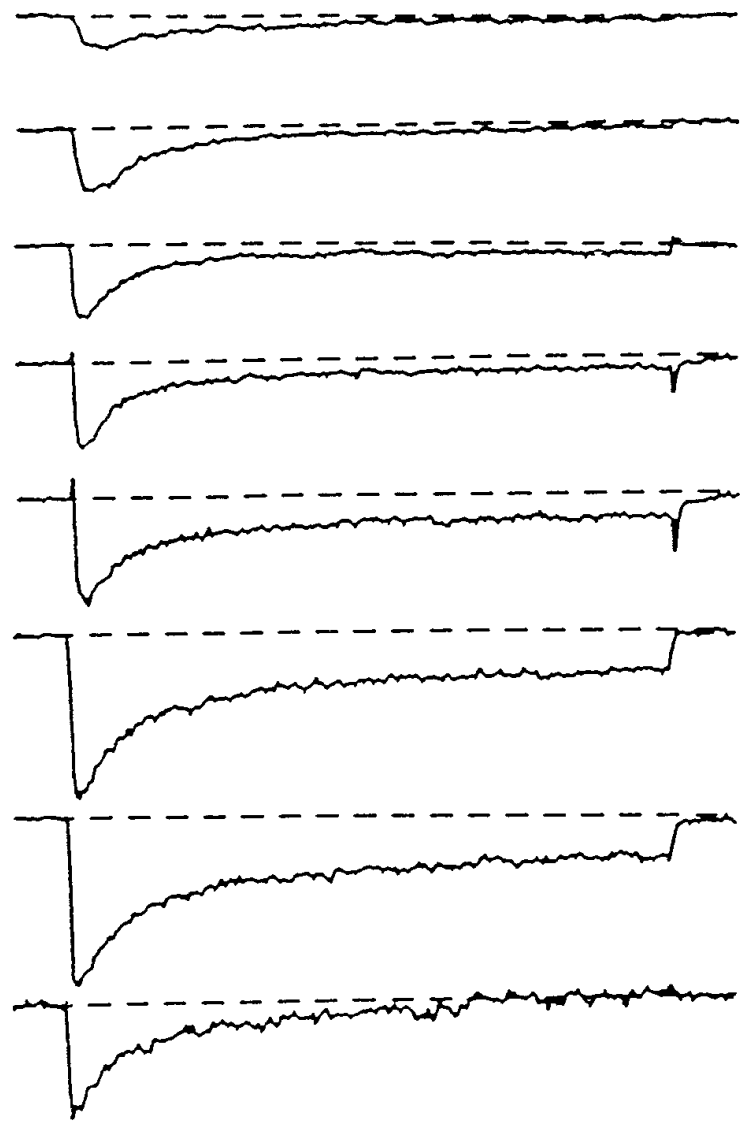

\section{Serum Treated}

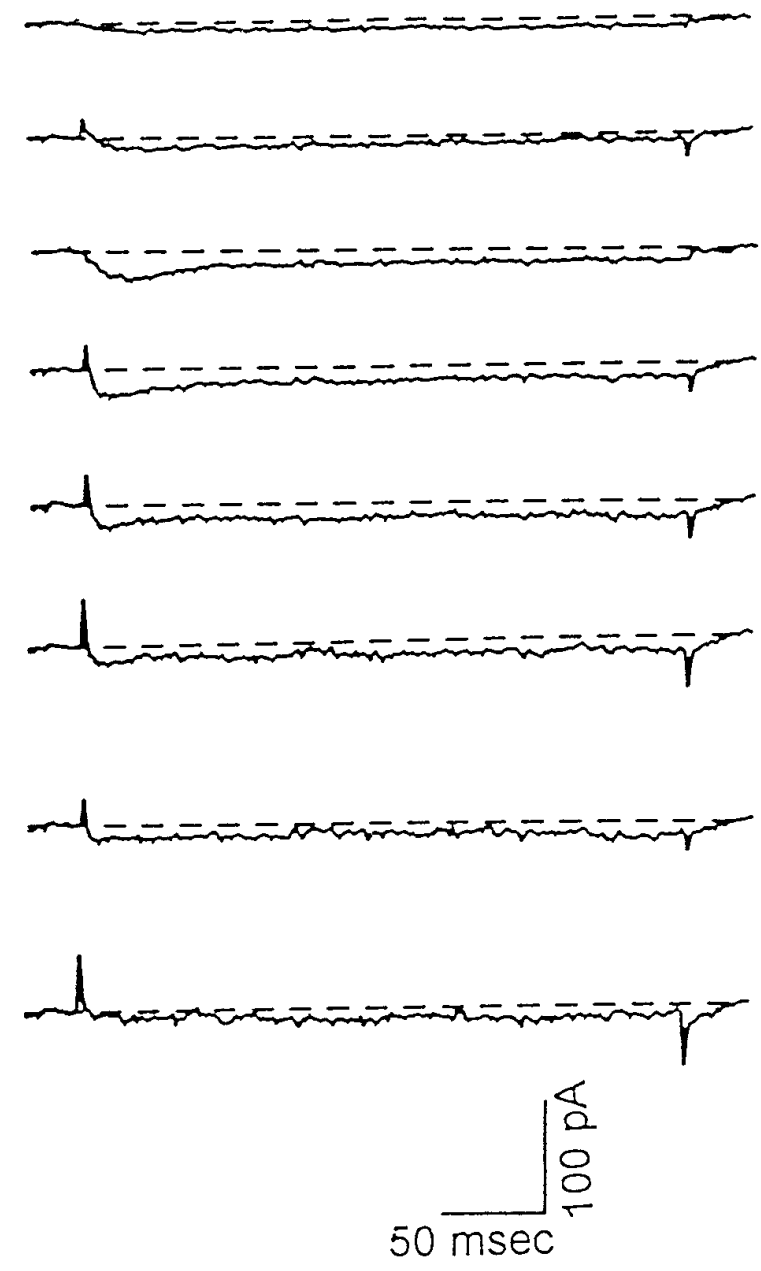

Figure 1. Voltage-activated calcium currents in a motoneuron treated with serum from a control individual (left) and a motoneuron treated with serum from LES Patient II (right). Representative calcium currents were elicited by $300 \mathrm{msec}$ depolarizing pulses to test potentials between -40 and $+30 \mathrm{mV}$ at $10 \mathrm{mV}$ intervals. LVA and HVA calcium currents are present in both control and treated cells. Note the prominent transient and sustained components of HVA current in the control motoneuron and that the HVA current in the LES serum-treated cell is predominantly sustained.

\section{Calcium conductances from control serum- and LES serum-treated motoneurons}

In addition to comparing current densities at specific test potentials, we also fitted the peak current-voltage relationship of individual cells as the sum of current through two populations of channels, each activating in accord with a Boltzmann function (García et al., 1996). These fits yielded a maximal conductance of the LVA and HVA components of current, which were averaged for each group of cells (Fig. 3). LVA and HVA maximal calcium conductances for LES serum-treated motoneurons were decreased, respectively, by 60 and $64 \%$ for Patient I, 90 and $91 \%$ for Patient II, 80 and $82 \%$ for Patient III, and 80 and $73 \%$ for Patient IV.

To determine whether serum-induced changes in calcium currents could have resulted from effects of LES sera on motoneuron growth, cell size was estimated from measurements of whole-cell capacitance. Averaged capacitances were similar for experimental $(26.8 \pm 2.9 \mathrm{pF}, n=41)$ and control $(23.2 \pm 1.6 \mathrm{pF}, n=17)$ cells, indicating that the effects of LES antibodies on whole-cell current were not a secondary result of altered cell growth. Additionally, in three cultures in which serum from Patients I or II was used, the percentage of cell survival was determined by counting the number of cells at time of recording relative to the number of cells plated. This ratio was not appreciably different between cells treated with control $(47,57$, and $59 \%)$ or LES $(42,54$, and $62 \%)$ serum.

\section{Potassium currents from control serum- and LES serum-treated motoneurons}

Because LES sera decreased both the LVA and HVA components of calcium currents, we examined potassium currents to determine whether the serum affected more than one family of voltage-gated ion channels in motoneurons. For these experiments, as well as those on calcium currents in muscle cells (see below), diminishing stocks prevented examination of the effects of sera from all of the patients. As in the case of calcium currents, the potassium currents were measured over a wide range of test potentials (Fig. 4, inset) and normalized to cell capacitance. Figure 4 compares averaged current-voltage relationships for control and serum-treated motoneurons. For strong depolarizations, the 


\section{$\mathrm{Ca}^{2+}$ Currents in Serum Treated Motoneurons}
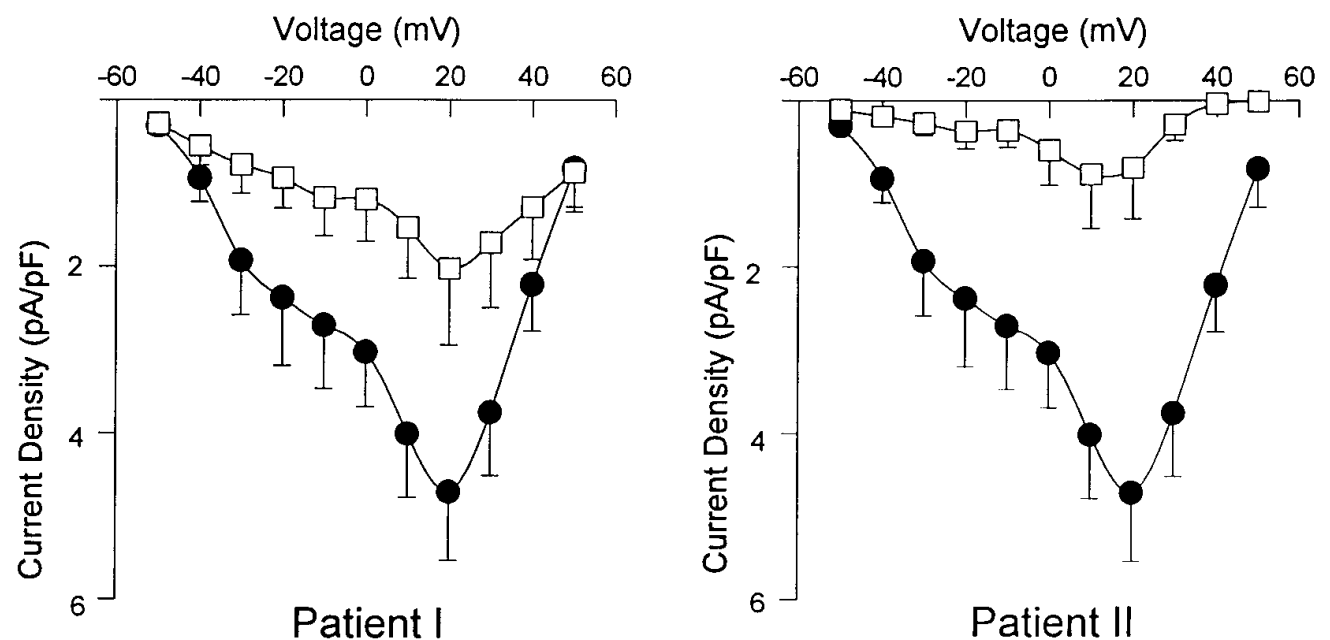

Figure 2. Peak calcium current density plotted as a function of test potential in control (circles) and LES serumtreated (squares) motoneurons. Average current density was smaller at each test potential for cells treated with serum from each of the four LES patients than for cells treated with control serum. The reduction in current was least substantial for cells treated with serum from Patient I $(n=11)$ and Patient III $(n=8)$ and greatest for cells treated with serum from Patient II $(n=11)$ and Patient IV $(n=10)$.
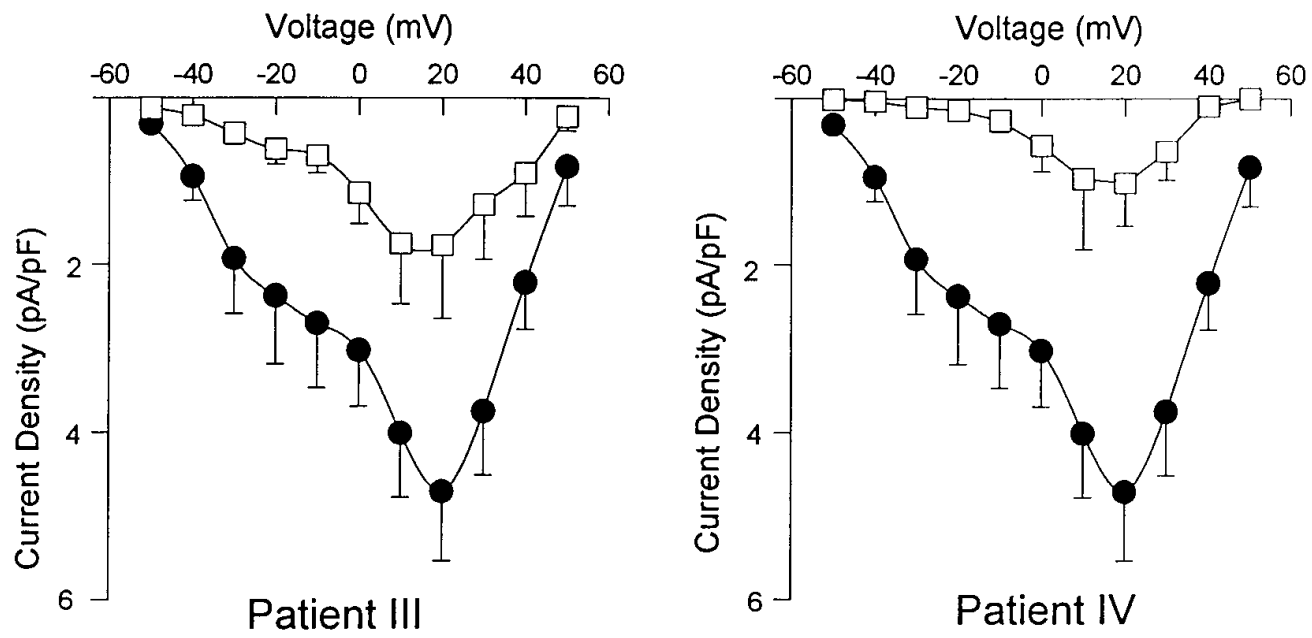

average potassium current densities in motoneurons treated with serum from Patients III (open squares) or IV (filled triangles) were slightly smaller or larger than control, respectively. However, these differences in average current density were not statistically significant for either patient.

\section{Effects of LES sera on calcium currents recorded from cardiac muscle and skeletal muscle}

Because LES sera have been reported to reduce calcium currents in a variety of cell types (see introductory remarks) and because neuromuscular weakness is a hallmark of the disease, we investigated the possibility that the sera affect calcium currents in cardiac or skeletal muscle cells via the use of protocols like those for the motoneurons. Averaged calcium current densities in cardiac myocytes treated with serum from Patients II or III were not significantly different from control at either low or high voltages (Fig. $5 A$ ). In contrast, serum from Patient IV significantly decreased the HVA calcium current density. The presence or absence of differences in current density were paralleled by differences in the maximal conductances, determined as described above for motoneurons. Thus, the maximal HVA calcium conductance was reduced for cells treated with serum from Patient IV but not for cells treated with serum from Patients II and III (Fig. 5B). Maximal LVA calcium conductance was unaffected by serum from any of the three patients. Although HVA currents were reduced in amplitude by serum from Patient IV, the kinetics were similar to those observed in control cells (Fig. 5C). As for cardiac myocytes, serum from Patient III had little effect on calcium currents in skeletal myotubes, whereas that from Patient IV caused a reduction in the HVA component of current (Fig. 6A). The kinetics and voltage dependence of HVA calcium currents in skeletal myotubes treated with serum from Patient IV were similar to those of control myotubes (Fig. 6B) and to HVA currents described previously in skeletal myotubes (Beam and Knudson, 1988).

\section{Pharmacology of residual calcium currents in LES serum-treated motoneurons}

Compared with control, calcium currents measured from motoneurons treated with LES serum decayed little during the test pulses, especially at high potentials (Fig. 1), which is reminiscent of L-type calcium current (Bean, 1989; Hess, 1990). Ad- 


\section{$\mathrm{Ca}^{2+}$ Conductance in Serum-Treated Motoneurons}

\section{Low Voltage Activated}

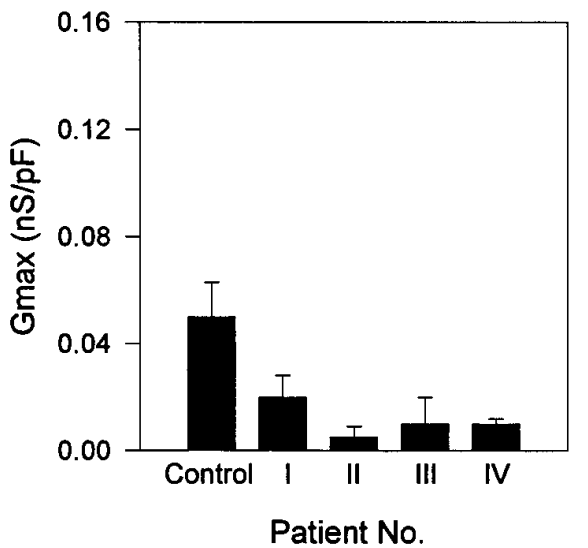

High Voltage Activated

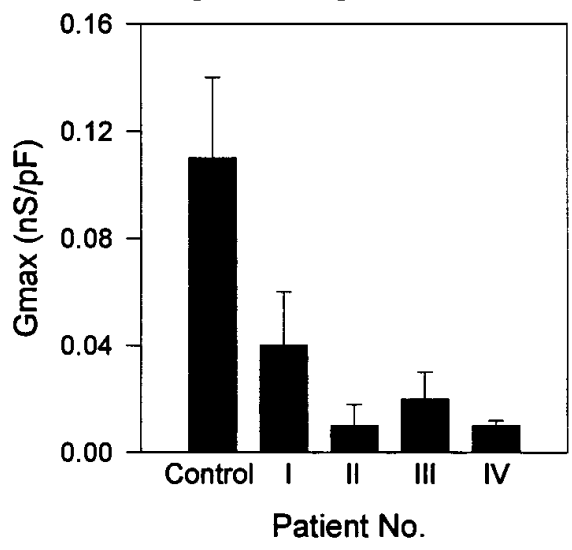

Figure 3. Maximal LVA $\left(G_{\operatorname{maxL}}\right)$ and HVA $\left(G_{\operatorname{maxH}}\right)$ calcium conductances for treated and control motoneurons. Calcium conductances were calculated by least-squares fitting of the experimental data with the equation:

$$
\begin{aligned}
I=\frac{G_{\mathrm{maxL}} *\left(V-V_{\mathrm{R}}\right)}{1+\exp \left[\left(V-V_{\mathrm{b} 1}\right) / k_{1}\right]} & \\
& +\frac{G_{\mathrm{maxH}} *\left(V-V_{\mathrm{R}}\right)}{1+\exp \left[\left(V-V_{\mathrm{b} 2}\right) / k_{2}\right]},
\end{aligned}
$$

in which $V$ is the test potential, $V_{\mathrm{R}}$ is the calcium current reversal potential, $G_{\operatorname{maxL}}$ and $G_{\operatorname{maxH}}$ are the maximal LVA and HVA conductances, respectively, $V_{\mathrm{b} 1}$ and $V_{\mathrm{b} 2}$ are potentials for half-maximal activation, and $k_{1}$ and $k_{2}$ are related to the steepness of the voltage dependence of activation. Reductions in both $G_{\operatorname{maxL}}$ and $G_{\operatorname{maxH}}$ were statistically significant $(p<0.05)$ for motoneurons treated with serum from any of the four patients. Following are average values \pm SEM for $V_{\mathrm{R}}, V_{\mathrm{b} 1}, k_{1}, V_{\mathrm{b} 2}$, and $k_{2}$, respectively: control $66.1(8.2),-27.3(2.6), 10.5$ (1.5), 13.8 (2.9), and 5.5 (0.7); Patient I 60.0 (9.2), $-27.5(2.4), 10.2(1.3), 13.1(2.9)$, and 3.9 (0.6); Patient II 84.0 (11.3), -33.2 (6.0), 8.7 (2.1), 7.8 (5.5), and 5.2 (3.0); Patient III $70.3(8.1),-34.2(5.0), 9.7(2.4), 8.3(1.8)$, and 7.6 (2.7); Patient IV 66.1 (5.7), -25.1 (4.8), $6.5(1.8), 6.2(2.4)$, and 5.8 (1.6). ditionally, only serum from Patient IV significantly altered calcium currents in muscle, which are primarily L-type (Bean, 1989; Hess, 1990). These observations suggest that a large portion of the residual calcium current in serum-treated motoneurons may be carried by L-type channels. To further examine the nature of the residual calcium current in LES serumtreated motoneurons, we used pharmacological methods. Nimodipine $(10 \mu \mathrm{M})$ was selected because it is an L-channel antagonist (Fox et al., 1987; McCarthy and TanPiengco, 1992), and $\omega$-CTx MVIIC $(5 \mu \mathrm{M})$ was selected because it blocks current via a number of different types of HVA calcium channels (including $\mathrm{N}, \mathrm{P}$, and $\mathrm{Q}$ ) but spares L-type calcium current (Hillyard et al., 1992).

As one approach for examining the pharmacology of the resid- ual current in LES serum-treated motoneurons, the motoneurons were incubated with either nimodipine or $\omega$-CTX MVIIC for at least $1.5 \mathrm{hr}$ before recording. In control serum-treated motoneurons, incubation with either $10 \mu \mathrm{M}$ nimodipine (Fig. $7 A$ ) or $5 \mu \mathrm{M}$ $\omega$-CTx MVIIC (Fig. 7B) did not seem to alter either voltage dependence or kinetics dramatically (compare with Fig. 1). Figure $7 C$ illustrates the effects of nimodipine and $\omega$-CTx MVIIC on peak current-voltage relationships in motoneurons treated with control serum (top), serum from Patient II (middle), or serum from Patient III (bottom). The circles plot average densities of the calcium currents from motoneurons not exposed to the calcium channel blockers. In control serum-treated motoneurons, $\omega$-CTx MVIIC (triangles) reduced the maximal HVA current by $70 \%$ $(n=7)$, whereas nimodipine (squares) caused only an $18 \%$ de-

\section{$\mathrm{K}^{+}$Currents in Serum Treated Motoneurons}

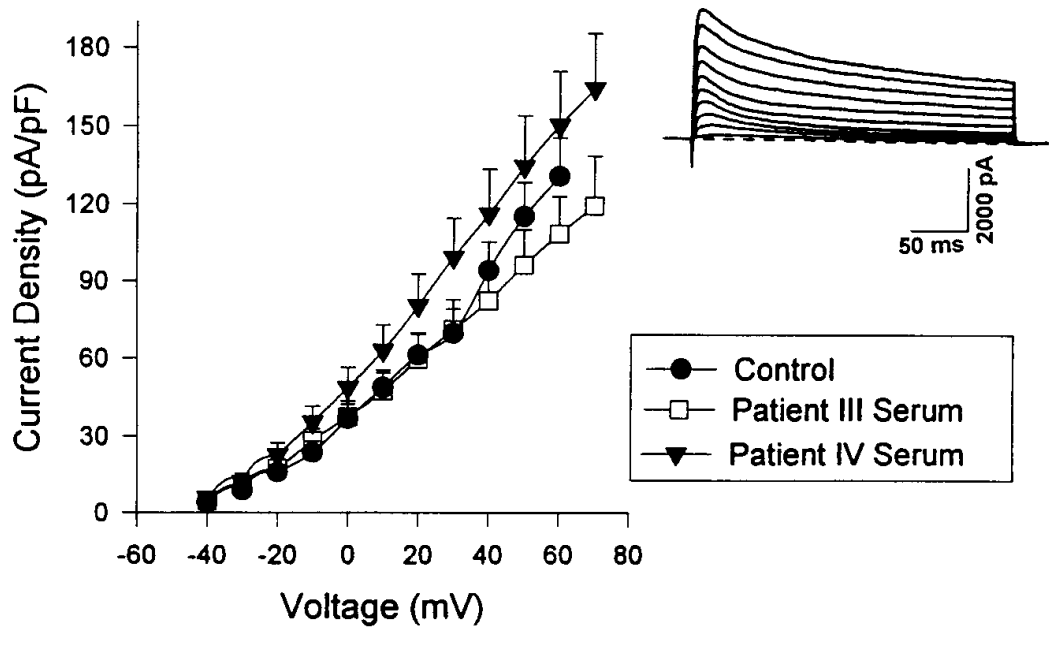

Figure 4. Normalized, peak potassium current density as a function of test potential in motoneurons treated with control serum (circles; $n=13$ ), serum from Patient III (squares; $n=$ 8 ), or serum from Patient IV (triangles; $n=8$ ). At high potentials, average potassium currents were slightly smaller than control for motoneurons treated with serum from $\mathrm{Pa}$ tient III and slightly greater for motoneurons treated with serum from Patient IV. However, these changes were not statistically significant. The inset shows a representative family of control potassium currents elicited by test potentials of -30 to $60 \mathrm{mV}$ at $10 \mathrm{mV}$ intervals. 

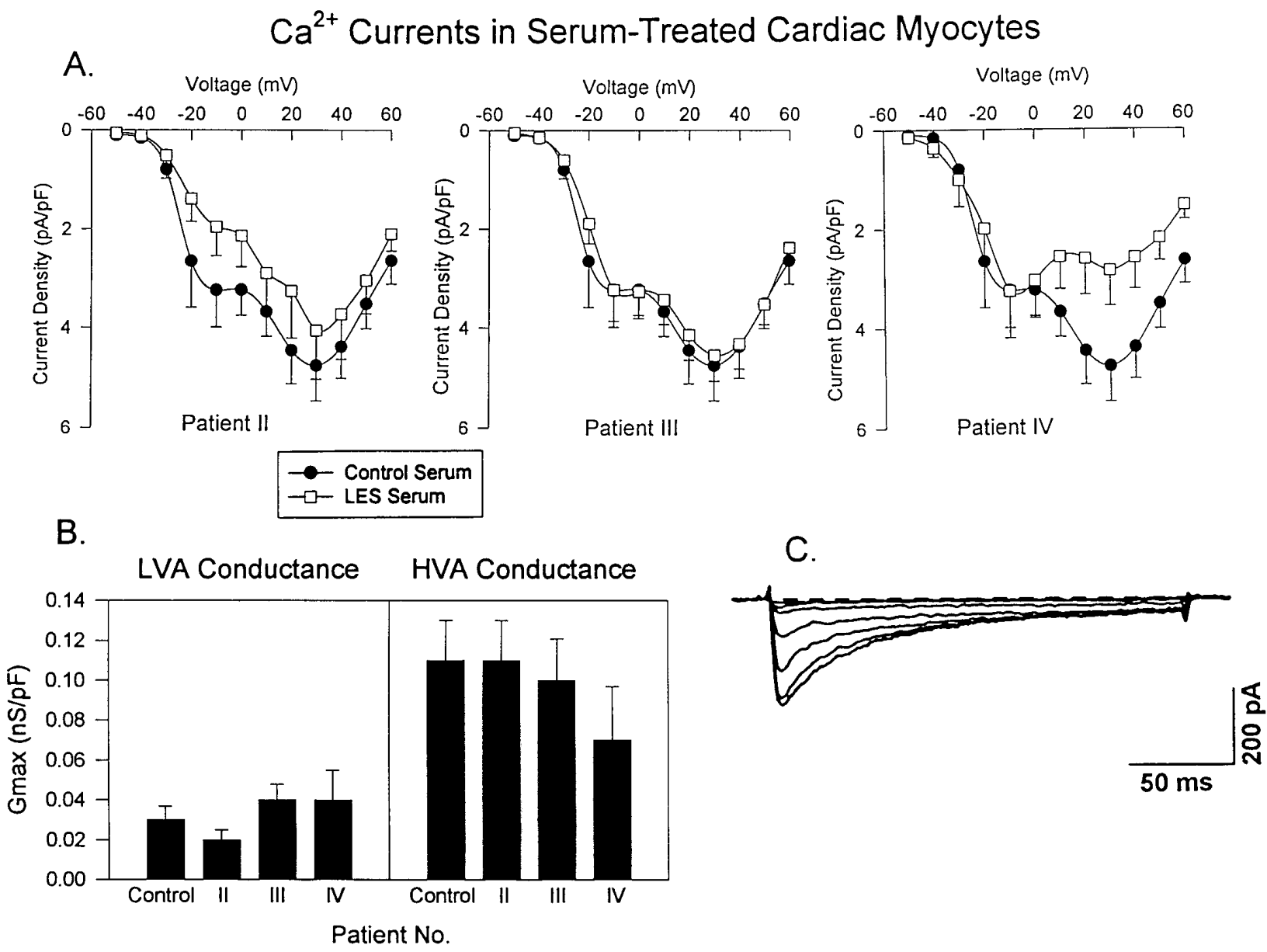

Figure 5. Comparison of calcium currents in cardiac myocytes treated with control or LES sera. $A$, Normalized, peak current-voltage relationships from control $(n=20)$ cardiomyocytes and cardiomyocytes treated with serum from Patients II $(n=12)$, III $(n=14)$, or IV $(n=14)$. The LVA current $(-20$ $\mathrm{mV})$ was not altered significantly by serum from any of the three patients; the only statistically significant $(p<0.05)$ decrease in HVA current $(+20 \mathrm{mV})$ was for cells treated with serum from Patient IV. $B$, Average maximal LVA $\left(G_{\operatorname{maxL}}\right)$ and HVA $\left(G_{\operatorname{maxH}}\right)$ calcium conductances for control and LES serum-treated cardiac myocytes. Differences in conductance were statistically significant only for cells treated with serum from Patient IV. $C$, Representative calcium currents evoked by test potentials ranging from -20 to $+30 \mathrm{mV}$ at $10 \mathrm{mV}$ intervals.

crease $(n=8)$. By contrast, $\omega$-CTx MVIIC essentially had no effect on the HVA calcium that remained in motoneurons treated with serum from Patients II and III ( $n=9$ for both), whereas nimodipine caused a large reduction in the residual HVA current; at $+10 \mathrm{mV}$, the reduction was $70 \%$ for Patient II $(n=7)$ and $73 \%$ for Patient III $(n=8)$.

In addition to prolonged bath application, acute perfusion of the calcium channel antagonists also was examined in control and Patient II serum-treated motoneurons. HVA current in control serum-treated motoneurons was decreased substantially by perfusion with $\omega$-CTx MVIIC but little affected by nimodipine (Fig. $8 A$ ). By contrast, in LES serum-treated motoneurons the HVA current was greatly reduced by perfusion with nimodipine (Fig. $8 B$, left) but not with $\omega$-CTx MVIIC (Fig. $8 B$, right, average reduction of $-3 \pm 5 \%$; $n=4)$. Even after a $15 \mathrm{~min}$ application of $\omega$-CTx MVIIC, the decrease was only 26 and $36 \%$ in two experiments, and much of this decrease may have been a consequence of time-dependent rundown. Figure $8 C$ shows the averaged normalized current as a function of time for control serum-treated motoneurons (left) and motoneurons treated with serum from Patient II (right). For control serum-treated motoneurons, maximal HVA current was reduced after 4 min perfusion with $\omega$-CTx MVIIC by $56 \pm 7 \%(n=3)$ but $<10 \%$ by nimodipine $(n=2)$. In motoneurons treated with serum from Patient II, the HVA current was not affected significantly by perfusion with $\omega$-CTx MVIIC but was reduced $>95 \%$ by perfusion with nimodipine $(n=2)$.

In summary, it seems that LES serum completely abolishes motoneuronal calcium currents from channels sensitive to $5 \mu \mathrm{M} \omega$-CTx MVIIC. However, LES serum may have even broader specificity for motoneuronal calcium channels than $\omega$-CTx MVIIC because (1) LES sera also reduce LVA calcium current (Fig. 2), (2) the average reduction in HVA current density is larger for LES sera (Fig. 2) than for $\omega$-CTx MVIIC (Fig. 7C), and (3) the kinetics of calcium current in control serum-treated cells incubated with $\omega$-CTx MVIIC (Fig. $7 B$ ) seems to differ from that in LES serum-treated motoneurons (Fig. 1). Despite this rather broad specificity, LES serum seems to spare motoneuronal L-type currents.

\section{DISCUSSION}

Since the first descriptions of LES as a neuromuscular disorder (Anderson et al., 1953; Lambert et al., 1956; Eaton and Lambert, 1957), a number of reports have provided evidence that the disease results from the production of autoantibodies that act on the presynaptic terminal (Elmqvist and Lambert, 1968; Lambert and Elmqvist, 1971; Cull-Candy et al., 1980; Kim, 1986). The hypothesis that neuromuscular weakness results from decreased 


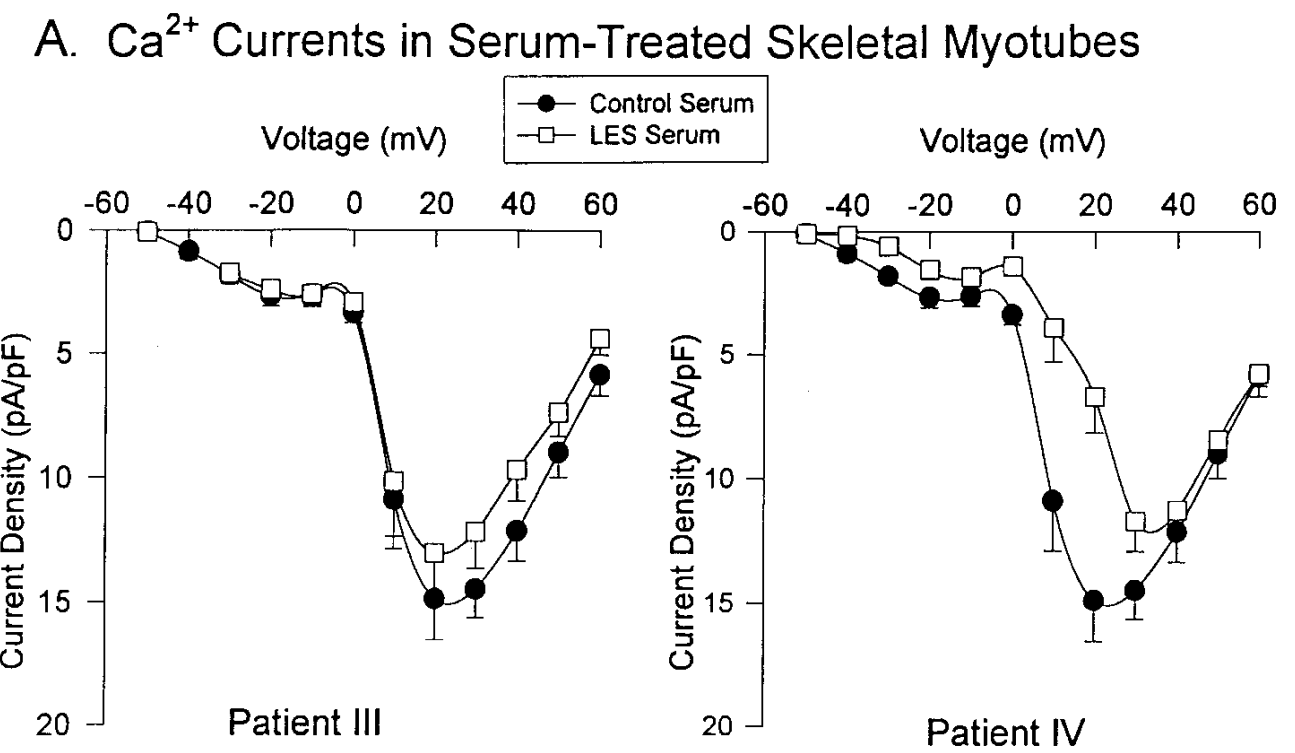

B.

\section{Control}

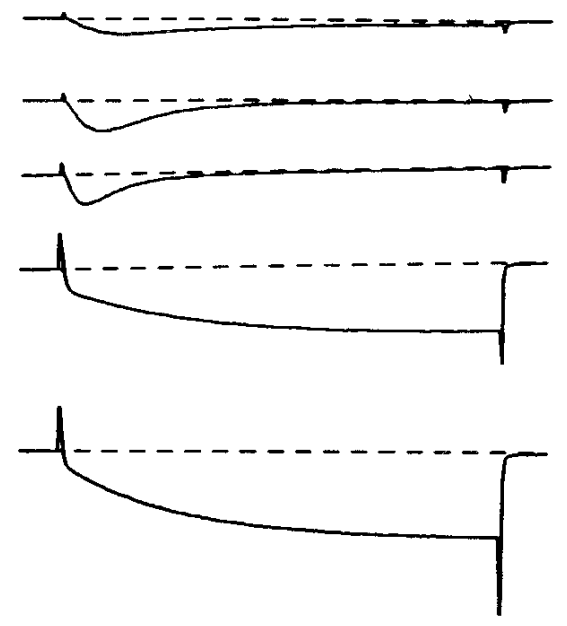

calcium entry at the nerve terminal was first proposed to explain why transmitter release in neuromuscular preparations from LES patients displayed an enhanced sensitivity to changes in calcium concentration (Elmqvist and Lambert, 1968; Cull-Candy et al., 1980). Support for this hypothesis came from structural studies showing the paucity and disruption of active zones and active zone particles (putative calcium channels) at nerve terminals exposed to LES serum (Fukunaga, 1982; Fukuoka et al., 1987a,b; Nagel et al., 1988). Subsequently, numerous studies have established a LES serum-induced decrease in calcium influx in a variety of cells (see introductory remarks). Recently it has been demonstrated that LES antibodies decrease mixed sodium and calcium currents at mouse nerve terminals (Smith et al., 1995). Here, we provide the first study directly quantifying the effects of LES sera on isolated calcium currents in motoneurons. Although the antibodies clearly target more than one type of calcium channel, their effects display specificity, because they have little effect on motoneuronal potassium currents and calcium currents in cardiac and skeletal muscle.
Figure 6. Effects of LES serum on calcium currents in skeletal myotubes. $A$, Normalized, peak current density versus voltage relationship for myotubes treated with control serum (circles; $n=$ 12 ) or serum (squares) from Patient III $(n=14)$ or IV $(n=14)$. Changes in LVA current were not significant. The decrease in HVA current was significant for Patient IV but not for Patient III. For Patient IV, $G_{\operatorname{maxH}}$ (determined as described in Fig. 3) was $0.21 \pm 0.06$ $\mathrm{nS} / \mathrm{pF}$ compared with $0.30 \pm 0.08 \mathrm{nS} / \mathrm{pF}$ in control. $B$, Representative current traces from a control (left) and Patient IV serum-treated (right) skeletal myotube at test potentials of $-30,-20,-10$, 20, and $30 \mathrm{mV}$. Serum from Patient IV had no obvious effect on voltage dependence or kinetics of calcium current.
Previous studies have supported the idea that LES effects are restricted to calcium channels. Thus, potassium currents in DRG cells (García et al., 1996) and sodium currents in chromaffin cells (Viglione et al., 1992) are not altered substantially by LES antibodies. The present report demonstrates that this is also true for potassium currents in motoneurons. Potassium currents were of particular interest because recent studies have raised the possibility that active zone particles may contain colocalized calcium and potassium channels (Roberts et al., 1990; Robitaille et al., 1993). If this is true for mammalian motoneurons, LES serum-induced destruction of active zones might result in simultaneous decreases in potassium and calcium currents. This did not occur in the cultured motoneurons used in our studies, although potassium and calcium channel colocalization may depend on the formation of neuromuscular synapses, which does not occur with the system we have used. Moreover, an additional argument against destruction of potassium channels in vivo is that decreased potassium current would tend to prolong the presynaptic depolarization and 

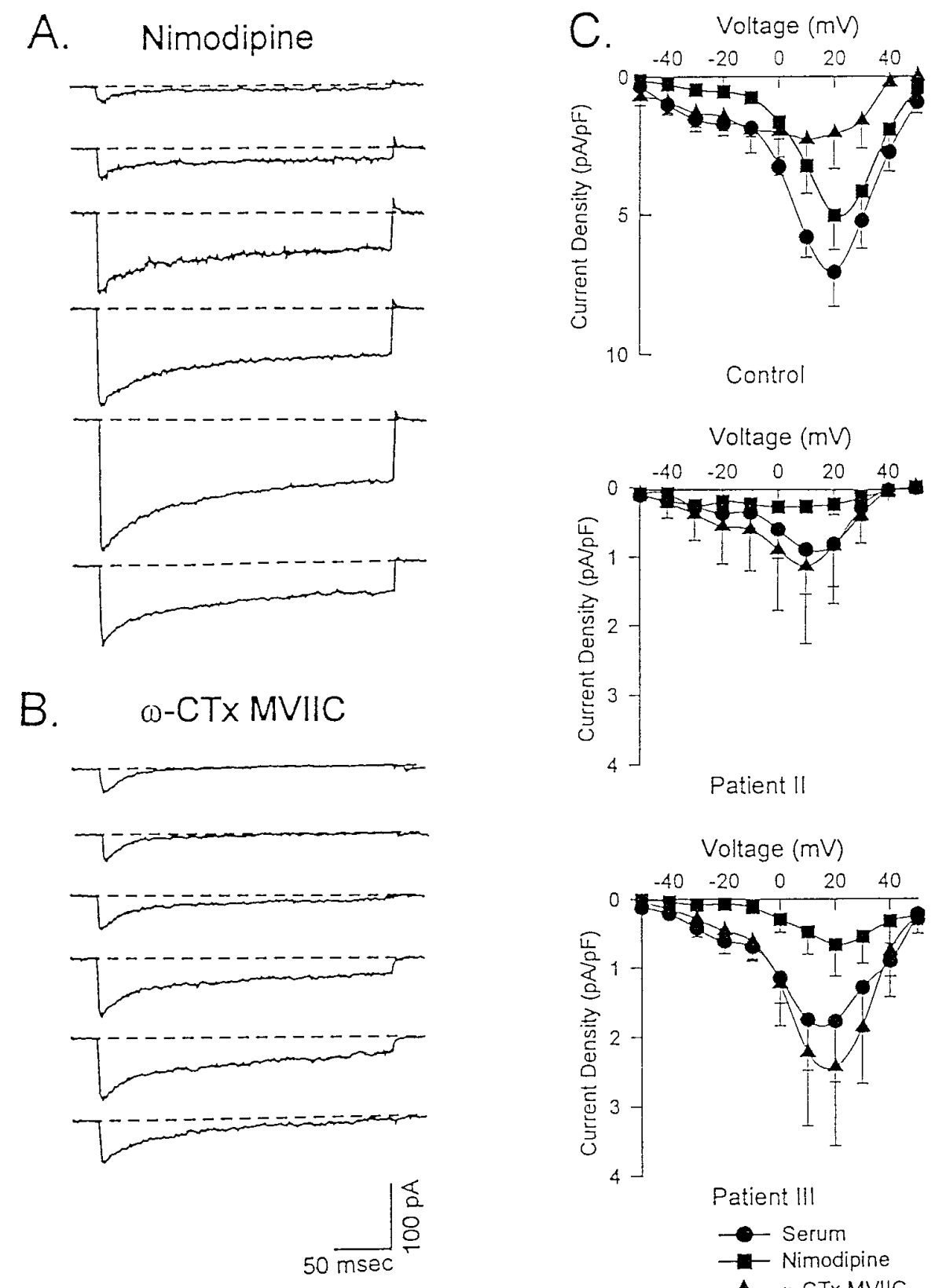

Figure 7. Representative calcium currents elicited at test potentials of $-30,-20,-10,10,20$, and 30 $\mathrm{mV}$ from motoneurons incubated in control serum and either $10 \mu \mathrm{M}$ nimodipine $(A)$ or $5 \mu \mathrm{M} \omega$-CTx MVIIC (B). $C$, Averaged, peak current density versus test potential in control and test serumtreated motoneurons that had been incubated 1.5 $\mathrm{hr}$ in medium with $10 \mu \mathrm{M}$ nimodipine (squares), 5 $\mu \mathrm{M} \omega$-CTx MVIIC (triangles), or without antagonist (circles; data replotted from Fig. 2). In control serum-treated motoneurons, LVA current was decreased significantly $(65 \%)$ by nimodipine but not by $\omega$-CTx MVIIC.
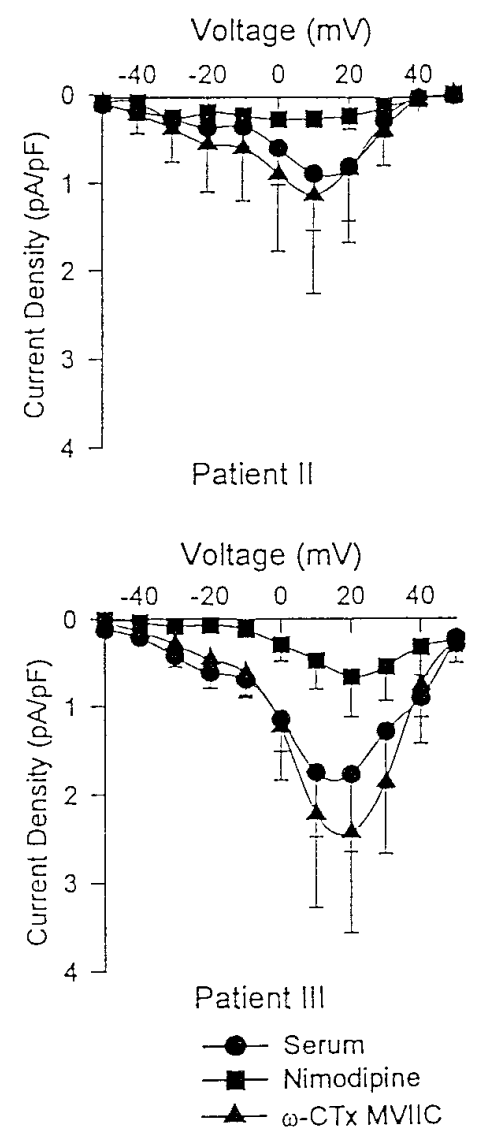

thus increase calcium influx, which would lessen the pathological consequences of destruction of calcium channels.

In various cells (Blandino and Kim, 1993; Grassi et al., 1994; Johnston et al., 1994; Lennon et al., 1995; García et al., 1996), LES antibodies have been shown to decrease currents or immunoprecipitate binding sites for antagonists associated with a number of calcium channel types, including LVA (T) and HVA (L, N, $\mathrm{P}, \mathrm{Q}$, others?). Our results demonstrate that in motoneurons, also, LES sera decrease both LVA and HVA calcium currents. Thus, LES sera do not target exclusively the channels controlling transmitter release, which is thought to be controlled by HVA, not LVA, channels (Hirning et al., 1988; Uchitel et al., 1992; Turner et al., 1993; Rossoni et al., 1994; Wheeler et al., 1994).

Although LES antibodies affect more than one type of calcium channel in motoneurons, the spared current seemed to be predominantly L-type. Thus, the spared current seemed to have slower activation, had a transient phase that was small compared

with the sustained phase, and was reduced substantially by a dihydropyridine antagonist. The sensitivity to the dihydropyridine antagonist contrasted with control motoneurons, in which micromolar nimodipine blocked $18 \%$ of HVA current. L-type current also represents only $6.6 \%$ of HVA calcium current in rat hypoglassal motoneurons (Umemiya and Berger, 1994). Additionally, $5 \mu \mathrm{M} \omega$-CTx MVIIC, which blocks several types of HVA calcium channels including N, P, and Q (Hillyard et al., 1992; Randall and Tsien, 1995), had little effect on the motoneuronal current spared by LES antibodies, whereas it blocked a large fraction of HVA current $(70 \%)$ in control motoneurons. In conclusion, LES antibodies nearly eliminated the non-L HVA current in murine motoneurons while sparing significant L-type current. This conclusion is in agreement with a recent report that a large fraction of the extracellularly recorded calcium current in mouse motor nerve terminals exposed to LES antibodies is blocked by dihydropyridines (Smith et al., 1995). 
A.

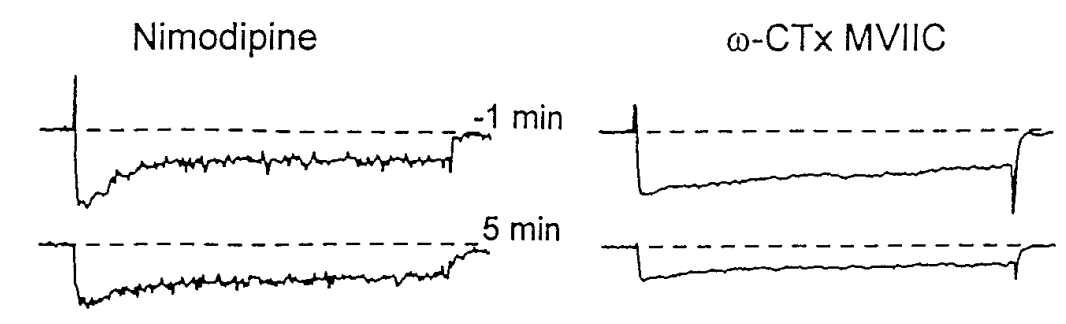

B.

Nimodipine

LES Serum Treated

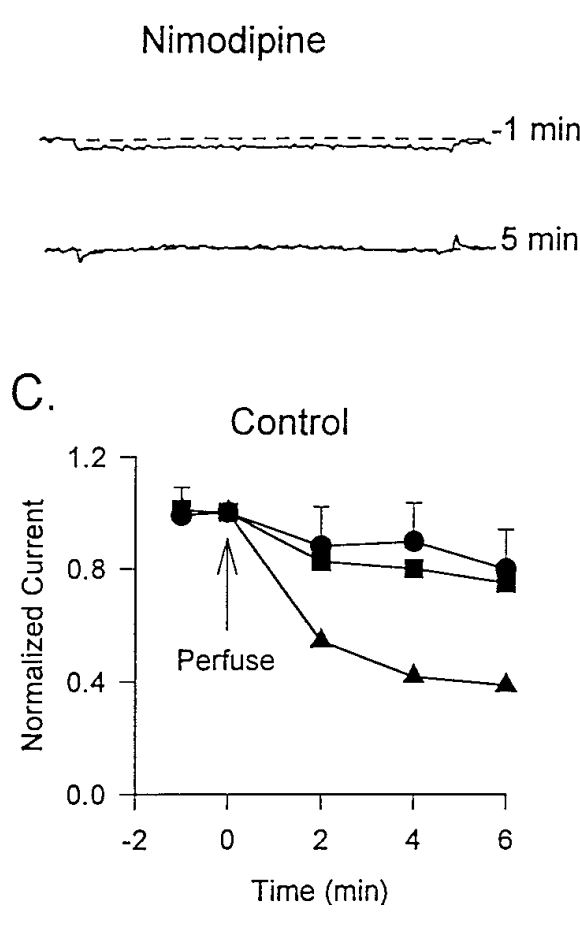

$\omega-C T \times$ MVIIC
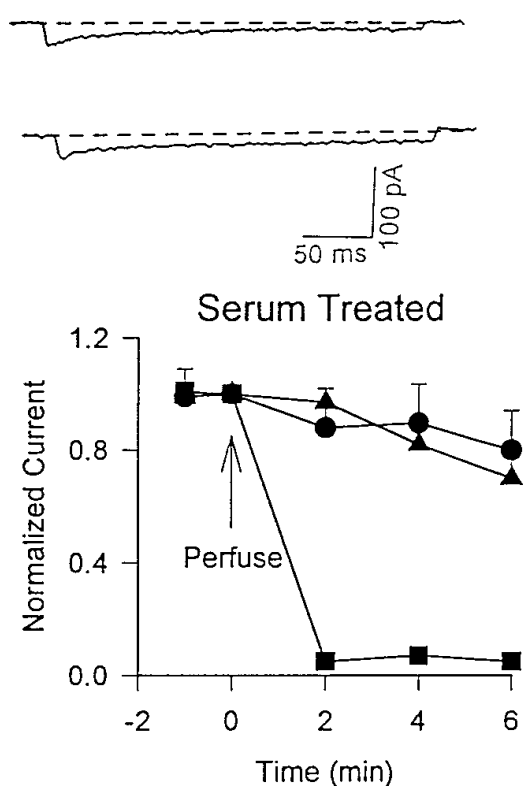

Figure 8. Effects of acute perfusion of calcium channel blockers on control serum- and Patient II serumtreated motoneurons. Calcium currents were evoked at $+10 \mathrm{mV}$ in control serum-treated motoneurons $(A)$ or Patient II serum-treated motoneurons $(B) 1$ min before and $5 \mathrm{~min}$ after acute perfusion with $10 \mu \mathrm{M}$ nimodipine (left) or $5 \mu \mathrm{M} \omega$-CTx MVIIC (right). C, Normalized peak calcium current at $+10 \mathrm{mV}$ is plotted with respect to time for motoneurons treated with control serum (left) or serum from Patient II (right) and exposed to either nimodipine (squares) or $\omega$-CTx MVIIC (triangles). The circles plot peak current as a function of time in control serum-treated motoneurons not exposed to either antagonist $(n=7)$.

LES sera seem to have a much more profound effect on calcium currents in motoneurons than in other native tissues examined (Fig. 9). For example, serum from Patients I, II, and III caused a moderate reduction of both LVA and HVA conductance in DRG neurons (the remaining conductance was $28-46 \%$ of control for LVA and 46-57\% for HVA). These sera caused a much larger reduction of calcium conductance in motoneurons (remaining conductance, $10-40 \%$ of control for LVA and $9-36 \%$ for HVA). The difference between DRG neurons and motoneurons was particularly striking for serum from Patient IV (LVA, 81 and $20 \%$ in DRGs and motoneurons, respectively; HVA, 91 and $27 \%$ in DRGs and motoneurons, respectively). LES sera have little effect on muscle calcium channels (Fig. 9). Of the serum examined, only that from Patient IV had an effect on muscle HVA (L-type) calcium conductance, and this effect was modest. Thus, our wholecell current measurements are in agreement with an earlier study that found no difference in the waveform of the cardiac action potential in ventricular muscle from mice injected with LES antibodies (Lang et al., 1988). The modest effect of the serum from Patient IV on muscle L-channels raises the possibility that some LES patients produce antibodies that cross-react with muscle. Alternatively, Patient IV was diagnosed as having both LES and myasthenia gravis (García et al., 1996). Thus, the effects of serum from Patient IV on muscle channels may be a consequence of neuromuscular inflammation by anti-AChR antibodies (Rash et al., 1976; Maselli et al., 1991).

The result in this paper that LES sera spare L-type channels in motoneurons seemingly contradicts some earlier reports demonstrating that LES antibodies affect L-type calcium channels in neuroblastoma X glioma (Peers et al., 1990) and bovine adrenal chromaffin cells (Blandino and Kim, 1993). Perhaps motoneurons express a different L-channel isoform than do these other tissues, because L-channels are encoded by at least three genes, and individual genes undergo alternative splicing (Perez-Reyes et al., 1990; Snutch and Reiner, 1992). Furthermore, LES sera from different patients may display differing degrees of cross-reactivity between calcium channel types. Alternatively, the channel categories affected may depend on the type of cell examined, as suggested by the data summarized in Figure 9.

LES antibodies seem to interact with a variety of, but not all, calcium channels. It is possible that the antibodies react with an antigen common to the $\alpha_{1}$ subunit of all affected channels. Calcium channel $\alpha_{1}$ subunits are evolutionarily and structurally related, although the non-L channels (classes A, B, and E) have been hypothesized to be closely related phylogenetically and to 


\section{Effects of LES Sera on Different Cell Types}
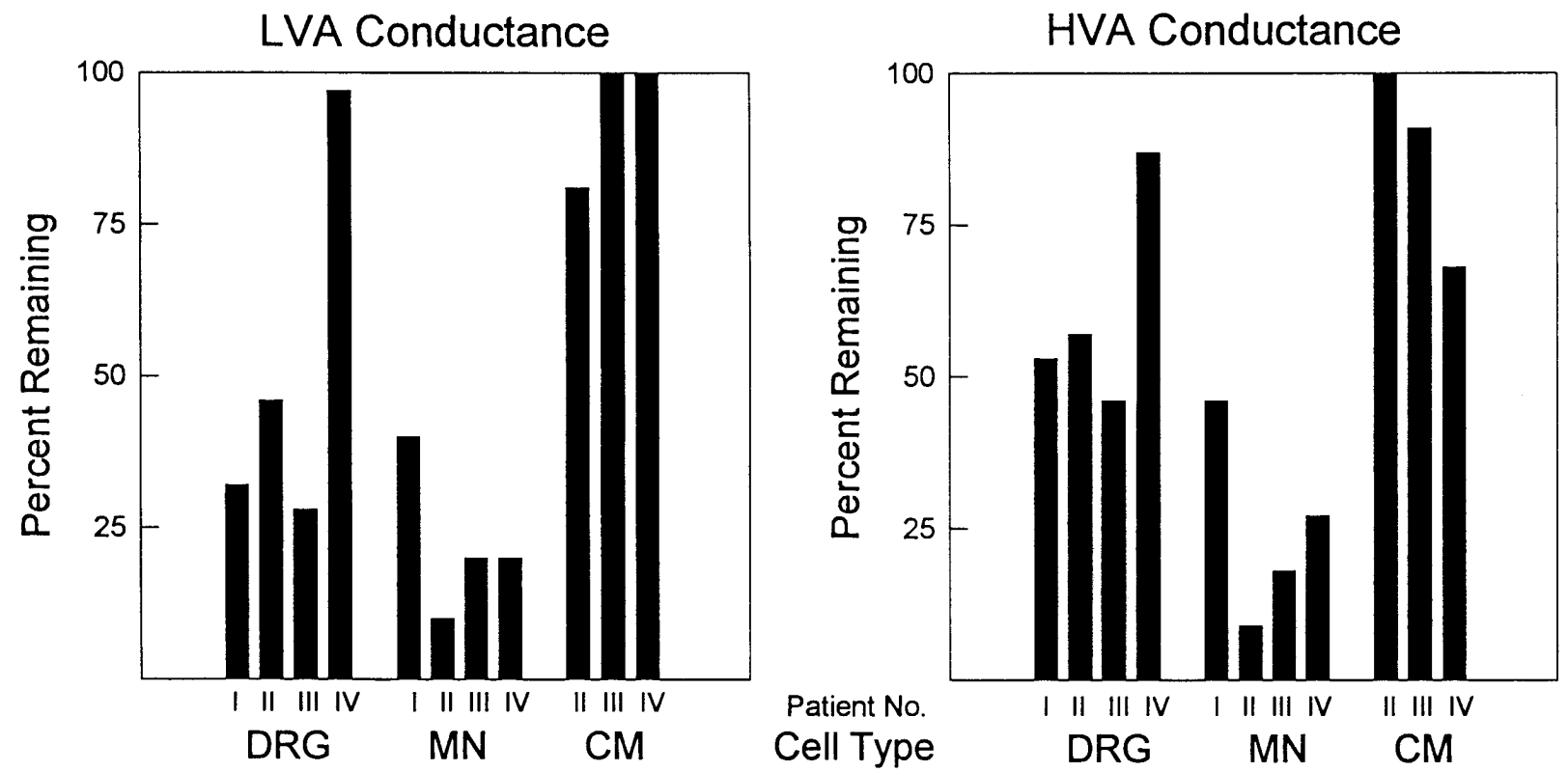

Figure 9. Summary of effects of LES sera on LVA and HVA calcium conductances in DRG neurons, motoneurons, and cardiac myocytes. The vertical axis plots the average calcium conductance remaining in treated cells as a percentage of control.

have diverged from L-type channels (classes C, D, and skeletal) at an early time point (Fujita et al., 1993; Zhang et al., 1993). It is equally plausible that the antibodies target an accessory subunit $\left(\alpha_{2} / \delta\right.$ or $\left.\beta\right)$ of $\alpha_{1}$ or some other channel-associated protein. One suggested candidate is the protein synaptotagmin (Leveque et al., 1992; Takamori et al., 1994), although this idea is controversial (Hajela and Atchison, 1995).

The present work raises another interesting question: why are motoneurons more profoundly affected? Among the possibilities are that, in motoneurons, the critical epitopes are more accessible, the targeted channel(s) comprise a larger fraction of the total, or the rates of calcium channel biosynthesis and degradation are different. Whatever the mechanism, the present results, together with previous work (García et al., 1996), show that LES antibodies preferentially target neurons and more profoundly affect motor than sensory neurons.

\section{REFERENCES}

Anderson HJ, Churchill-Davidson HC, Richardson AT (1953) Bronchial neoplasm with myasthenia: prolonged apnea after administration of succinylcholine. Lancet 2:1291-1293.

Beam KG, Knudson CM (1988) Calcium currents in embryonic and neonatal mammalian skeletal muscle. J Gen Physiol 91:781-798.

Bean BP (1989) Classes of calcium channels in vertebrate cells. Annu Rev Physiol 51:367-384.

Blandino JK, Kim YI (1993) Lambert-Eaton syndrome IgG inhibits dihydropyridine-sensitive, slowly inactivating calcium channels in bovine adrenal chromaffin cells. Ann NY Acad Sci 681:394-397.

Bowersox SS, Miljanich GP, Sugiura Y, Li C, Nadasdi L, Hoffman BB, Ramachandran J, Ko CP (1995) Differential blockade of voltagesensitive calcium channels at the mouse neuromuscular junction by novel $\omega$-conopeptides and $\omega$-agatoxin IVA. J Pharmacol Exp Ther 273:248-256.

Couteaux R, Pecot-Dechavassine M (1970) Vesicules synaptiques et poches au niveau des "zones actives" de la jonction neuromusculaire. C R Acad Sci Series D 271:2346-2349.
Cull-Candy SG, Miledi R, Trautmann A, Uchitel OD (1980) On the release of transmitter at normal, myasthenia gravis, and myasthenic syndrome-affected human end-plates. J Physiol (Lond) 299:621-638.

Eaton LM, Lambert EH (1957) Electromyography and electric stimulation of nerves in diseases of motor unit: observations on myasthenic syndrome associated with malignant tumors. JAMA 163:1117-1124.

Elmqvist D, Lambert EH (1968) Detailed analysis of neuromuscular transmission in a patient with the myasthenic syndrome sometimes associated with bronchogenic carcinoma. Mayo Clin Proc 43:689-713.

Fox AP, Nowycky MC, Tsien RW (1987) Kinetic and pharmacological properties distinguishing three types of calcium currents in chick sensory neurones. J Physiol (Lond) 394:149-172.

Fujita Y, Mynlieff M, Dirksen RT, Kim MS, Niidome T, Nakai J, Friedrich T, Iwabe N, Miyata T, Furuichi T, Furutama D, Mikoshiba K, Mori Y, Beam KG (1993) Primary structure and functional expression of the $\omega$-conotoxin-sensitive $\mathrm{N}$-type calcium channel from rabbit brain. Neuron 10:585-598.

Fukunaga H, Engel AG, Osame M, Lambert EH (1982) Paucity and disorganization of presynaptic membrane active zones in the LambertEaton myasthenic syndrome. Muscle Nerve 5:686-697.

Fukunaga H, Engel AG, Lang B, Newsom-Davis J, Vincent A (1983) Passive transfer of Lambert-Eaton myasthenic syndrome with IgG from man to mouse depletes the presynaptic membrane active zones. Proc Natl Acad Sci USA 80:7636-7640.

Fukuoka T, Engel AG, Lang B, Newsom-Davis J, Prior C, Wray DW (1987a) Lambert-Eaton myasthenic syndrome. I. Early morphological effects of IgG on the presynaptic membrane active zones. Ann Neurol 22:193-199.

Fukuoka T, Engel AG, Lang B, Newsom-Davis J, Vincent A (1987b) Lambert-Eaton myasthenic syndrome. II. Immunoelectron microscopy localization of $\operatorname{IgG}$ at the mouse motor end-plate. Ann Neurol 22:200-211.

García KD, Mynlieff M, Sanders DB, Walrond JW, Beam KG (1996) Lambert-Eaton sera reduce low-voltage and high-voltage activated calcium currents in murine dorsal root ganglion neurons. Proc Natl Acad Sci USA, in press.

Grassi C, Magnelli V, Carbelli V, Sher E, Carbone E (1994) Inhibition of low- and high-threshold calcium channels of human neuroblastoma IMR32 cells by Lambert-Eaton myasthenic syndrome (LEMS) IgGs. Neurosci Lett 181:50-56. 
Hajela RK, Atchison WD (1995) The proteins synaptotagmin and syntaxin are not general targets of Lambert-Eaton myasthenic syndrome autoantibody. J Neurochem 654:1245-1251.

Hamill OP, Morty A, Neher E, Sakmann B, Sigworth FJ (1981) Improved patch-clamp techniques from high-resolution current recordings from cells and cell-free membrane patches. Pflügers Arch 391:85-100.

Hess P (1990) Calcium channels in vertebrate cells. Annu Rev Neurosci 13:337-356.

Heuser JE, Reese TS, Dennis MJ, Jan Y, Jan L, Evans L (1979) Synaptic vesicle exocytosis captured by quick freezing and correlated with quantal transmitter release. J Cell Biol 81:275-300.

Hillyard DR, Monje VD, Mintz IM, Bean BP, Nadasdi L, Ramachandran J, Miljanich G, Azimi-Zoonooz A, Mcintosh JM, Cruz LJ, Imerial JS, Olivera BM (1992) A new conus peptide ligand for mammalian presynaptic calcium channels. Neuron 9:69-77.

Hirning LD, Fox AP, McCleskey EW, Olivera BM, Thayer SA, Miller RJ (1988) Dominant role of N-type calcium channels in evoked release of norepinephrine from sympathetic neurons. Science 239:57-61.

Hong SJ, Chang, CC (1995) Inhibition of acetylcholine release from mouse motor nerve by a P-type calcium channel blocker, $\omega$-agatoxin IVA. J Physiol (Lond) 482:283-290.

Honig MG, Hume RI (1986) Fluorescent carbocyanine dyes allow living neurons of identified origin to be studies in long-term cultures. J Cell Biol 103:171-187.

Isselbacher KJ, Adams RD, Braunwald E, Petersdorf RG, Wilson JD (1980) Laboratory values of clinical importance. In: Principles of internal medicine, pp A2-A3. New York: McGraw-Hill.

Johnston I, Lang B, Leys K, Newsom-Davis J (1994) Heterogeneity of calcium channel autoantibodies detected using a small-cell lung cancer line derived from a Lambert-Eaton myasthenic syndrome patient. Neurology 44:334-338.

Kim YI (1986) Passively transferred Lambert-Eaton syndrome in mice receiving purified IgG. Muscle Nerve 9:523-530.

Kim YI, Neher E (1988) IgG from patients with Lambert-Eaton syndrome blocks voltage-dependent calcium channels. Science 239:405-408.

Kim YI, Blandino JK, O'Shaughnessy TJ (1993) Inhibitory action of Lambert-Eaton syndrome IgG on calcium currents in a thyroid c-cell line. Ann NY Acad Sci 681:398-401.

Lambert EH, Elmqvist D (1971) Quantal components of end-plate potentials in the myasthenic syndrome. Ann NY Acad Sci 183:183-199.

Lambert EH, Eaton LM, Rooke ED (1956) Defects of neuromuscular conduction associated with malignant neoplasms. Am J Physiol 187:612-613.

Lang B, Newsom-Davis J, Wray DW (1988) The effect of LambertEaton myasthenic syndrome antibody on slow action potentials in mouse cardiac ventricle. Proc R Soc Lond [Biol] 235:103-110.

Lennon VA, Kryzer TJ, Griesmann MS, O'Suilleabhasin PE, Windebank AJ, Woppmann A, Miljanich GP, Lambert EH (1995) Calciumchannel antibodies in the Lambert-Eaton syndrome and other paraneoplastic disorders. N Engl J Med 332:1467-1474.

Leveque C, Hoshino T, David P, Shoji-Kasai Y, Leys K, Omori A, Lang B, Far EO, Sato K, Martin-Moutot N, Newsom-Davis J, Takahashi M, Seagar MJ (1992) The synaptic vesicle protein synaptotagmin associates with calcium channels and is a putative Lambert-Eaton myasthenic syndrome antigen. Proc Natl Acad Sci USA 89:3625-3629.

Leys K, Lang B, Vincent A, Newsom-Davis J (1989) Calcium channel autoantibodies in Lambert-Eaton myasthenic syndrome. Lancet 2:1107.

Login IS, Kim YI, Judd AM, Spangelo BL, MacLeod RM (1987) Immunoglobulins of Lambert-Eaton myasthenic syndrome inhibit rat pituitary hormone release. Ann Neurol 22:610-614.

Masselli RA, Richman DP, Wollmann RL (1991) Inflammation at the neuromuscular junction in myasthenia gravis. Neurology 41:1497-1504.

McCarthy RT, TanPiengco PE (1992) Multiple types of high-threshold calcium channels in rabbit sensory neurons: high-affinity block by nimodipine. J Neurosci 12:2225-2234.

Milligan CE, Oppenheim RW, Schwartz LM (1994) Motoneurons deprived of trophic support in vitro require new gene expression to undergo programmed cell death. J Neurobiol 25:1005-1016.

Mintz IM, Adams ME, Bean BP (1992) P-type calcium channels in rat central and peripheral neurons. Neuron 9:85-95.

Mynlieff M, Beam KG (1992a) Developmental expression of voltagedependent calcium currents in identified mouse motoneurons. Dev Biol 152:407-410.

Mynlieff M, Beam KG (1992b) Characterization of voltage-dependent calcium currents in mouse motoneurons. J Neurophysiol 68:85-92.
Mynlieff M, Beam KG (1994) Adenosine acting at an A1 receptor decreases $\mathrm{N}$-type calcium current in mouse motoneurons. J Neurosci $14: 3628-3634$

Nagel A, Engel AG, Newsom-Davis J, Fukuoka T (1988) LambertEaton myasthenic syndrome IgG depletes presynaptic membrane active zone particles by antigenic modulation. Ann Neurol 24:552-558.

Nowycky MC, Fox AP, Tsien RW (1985) Three types of neuronal calcium channel with different calcium agonist sensitivity. Nature 316:440-443.

Olivera BM, Miljanich GP, Ramachandran J, Adams ME (1994) Calcium channel diversity and neurotransmitter release: the $\omega$-conotoxins and $\omega$-agatoxins. Annu Rev Biochem 63:823-867.

Peers C, Lang B, Newsom-Davis J, Wray DW (1990) Selective action of myasthenic syndrome antibodies on calcium channels in a rodent neuroblastoma X glioma cell line. J Physiol (Lond) 421:293-308.

Perez-Reyes E, Wei X, Castellano A, Birnbaumer L (1990) Molecular diversity of L-type calcium channels. J Biol Chem 265:20430-20436.

Randall A, Tsien RW (1995) Pharmacological dissection of multiple types of calcium channel currents in rat cerebellar granule neurons. J Neurosci 15:2995-3012.

Rash JE, Albuquerque EX, Hudson CS, Mayer RF, Satterfield JR (1976) Studies of human myasthenia gravis: electrophysiological and ultrastructural evidence compatible with antibody attachment to the acetylcholine receptor complex. Proc Natl Acad Sci USA 73:4584-4588.

Regan LJ, Sah DWY, Bean BP (1992) Calcium channels in rat central and peripheral neurons: high-threshold current resistant to dihydropyridine blockers and $\omega$-conotoxin. Neuron 6:269-280.

Roberts A, Perera S, Lang B, Vincent A, Newsom-Davis J (1985) Paraneoplastic myasthenic syndrome $\mathrm{IgG}$ inhibits ${ }^{45} \mathrm{Ca}$ flux in a human small-cell carcinoma line. Nature 317:737-739.

Roberts WM, Jacobs RA, Hudspeth AJ (1990) Colocalization of ion channels involved in frequency selectivity and synaptic transmission at presynaptic active zones of hair cells. J Neurosci 10:3664-3684.

Robitaille R, Garcia ML, Kaczorowski GJ, Charlton MP (1993) Functional colocalization of calcium and calcium-gated potassium channels in control of transmitter release. Neuron 11:645-655.

Rossoni G, Berti G, La Maestra L, Clementi G (1994) $\omega$-Conotoxin GVIA binds to and blocks rat neuromuscular junction. Neurosci Lett 176:185-188.

Smith DO, Conklin MW, Jensen PJ, Atchison WD (1995) Decreased calcium currents in motor nerve terminals of mice with Lambert-Eaton myasthenic syndrome. J Physiol (Lond) 487:115-123.

Smith RG, Vaca K, McManaman J, Appel SH (1986) Selective effects of skeletal muscle extract fractions on motoneuron development in vitro. J Neurosci 6:439-447.

Snutch TP, Reiner PB (1992) $\mathrm{Ca}^{2+}$ channels: diversity of form and function. Curr Opin Neurobiol 2:247-253.

Stanley EF, Goping G (1991) Characterization of a calcium current in a vertebrate cholinergic presynaptic nerve terminal. J Neurosci 11:985-993.

Takamori M, Hamada T, Komai K, Takahashi M, Yoshida A (1994) Synaptotagmin can cause an immune-mediated model of LambertEaton myasthenic syndrome in rats. Ann Neurol 35:74-80.

Turner TJ, Adams ME, Dunlop K (1993) Multiple calcium channel types coexist to regulate synaptosomal neurotransmitter release. Proc Natl Acad Sci USA 90:9518-9522.

Uchitel OD, Protti DA, Sanchez VA, Cherksey, BD, Sugimori M, LLinas R (1992) P-type voltage-dependent calcium channel mediates presynaptic calcium influx and transmitter release in mammalian synapses. Proc Natl Acad Sci USA 89:3330-3333.

Umemiya M, Berger AJ (1994) Properties and function of low- and high-voltage-activated calcium channels in hypoglossal motoneurons. J Neurosci 14:5652-5660.

Viglione MP, Creutz CE, Kim YI (1992) Lambert-Eaton syndrome: antigen-antibody interaction and calcium current inhibition in chromaffin cells. Muscle Nerve 15:1325-1333.

Wheeler DB, Randall A, Tsien RW (1994) Roles of N-type and Q-type calcium channels in supporting hippocampal synaptic transmission. Science 264:107-111.

Yoshikami D Bagabaldo Z, Olivera BM (1989) The inhibitory effects of omega-conotoxins on Ca channels and synapses. Ann NY Acad Sci 560:230-248.

Zhang JF, Randall AD, Ellinor PT, Horne WA, Sather WA, Tanabe T, Schwarz TL, Tsien RW (1993) Distinctive pharmacology and kinetics of cloned neuronal calcium channels and their possible counterparts in mammalian CNS neurons. Neuropharmacology 32:1075-1088. 